\title{
Causal correlation paths across cortical areas in decision making
}

\author{
Adrià Tauste Campo ${ }^{1 *}$, Marina Martinez-Garcia', Verónica Nácher², Gustavo Deco ${ }^{1}$, Ranulfo Romo² \\ From The Twenty Third Annual Computational Neuroscience Meeting: CNS*2014 \\ Québec City, Canada. 26-31 July 2014
}

We study how neural spike activity encode, integrate and communicate information across different brain areas. An ideal paradigm to study this problem is the vibrotactile discrimination task designed by Romo et al. [1]. This is a complex process, which requires communicating information from the sensory areas that perceive the tactile stimuli to superior areas that integrate this sensory information and report the decision. Previous works on this task have characterized the role played by sensory and motor areas using the correlation between single-neuron rate responses and the task variables, namely the two stimulation frequencies and the decision [2]. In the present work, we investigate the causal correlations that arise between nearby and distant cells while the monkey is performing the task under fixed stimulation frequencies.

To this end, we use simultaneous multiple-cell recordings to estimate causal across five cortical areas (S1, S2, SMA, DPC and M1) over the time course of the discrimination task. Causal correlations are estimated with a sequential universal estimator of the directed information based on the context-tree weighting algorithm [3,4]. Statistical tests on the estimates for four stimulation frequency pairs suggest that significant causal correlations ('causal paths') are highly distributed across the studied cortical areas and are equally present in feedforward and feedback interactions between sensory and motor areas. Furthermore, the percentage of incoming causal paths is steady during the time course of the task for destination areas S2, SMA, DPC and M1 while it decays during the stimulation periods for S1. The task-specificity of these results is assessed by a control task, where the monkey receives both stimuli but it is requested not to perform the task.

\footnotetext{
* Correspondence: adria.tauste@upf.edu

'Department of Information and Communication Technologies, Universitat Pompeu Fabra, Barcelona, 08018 Spain

Full list of author information is available at the end of the article
}

Specifically, during the passive stimulation task there is an abrupt decrease in the number of causal correlations after the first stimulation, which is shown to be independent of the spike-train variability of each area.

\section{Conclusions}

Neuronal causal correlation paths that are specific to the discriminations task are ubiquitous, bidirectional and remain approximately constant along the task in both sensory and motor areas. These findings are robust to the stimulation pair under study and the spike-train variability of each area.

\section{Acknowledgements}

A. Tauste Campo agrees funding from the European Union under the 7th Framework Programme, grants FP7-PEOPLE-2013-IEF no. 329837.

\section{Authors' details}

'Department of Information and Communication Technologies, Universitat Pompeu Fabra, Barcelona, 08018 Spain. ${ }^{2}$ Instituto de Fisiología CelularNeurociencias, Universidad Nacional Autónoma de México, 04510 México D. F., México.

Published: 21 July 2014

\section{References}

1. Hernández A, Nácher V, Luna R, Zainos A, Lemus L, Alvarez M, Romo R: Decoding a perceptual decision process across cortex. Neuron 2010, 66(2):300-314

2. Shadlen MN, Newsome WT: Neural basis of a perceptual decision in the parietal cortex (area LIP) of the rhesus monkey. Journal of Neurophysiology 2001, 86(4):1916-1936.

3. Willems FM, Shtarkov YM, Tjalkens TJ: The context-tree weighting method: Basic properties. IEEE Transactions on Information Theory 1995, 41(3):653-664.

4. Jiao J, Permuter H, Zhao L, Kim Y, Weissman T: Universal estimation of directed information. IEEE Transactions on Information Theory 2013, 59(10):6220-6242.

doi:10.1186/1471-2202-15-S1-O7

Cite this article as: Campo et al:: Causal correlation paths across cortical areas in decision making. BMC Neuroscience 2014 15(Suppl 1):O7.
() Biomed Central

(c) 2014 Campo et al; licensee BioMed Central Ltd. This is an Open Access article distributed under the terms of the Creative Commons Attribution License (http://creativecommons.org/licenses/by/4.0), which permits unrestricted use, distribution, and reproduction in any medium, provided the original work is properly cited. The Creative Commons Public Domain Dedication waiver (http:// creativecommons.org/publicdomain/zero/1.0/) applies to the data made available in this article, unless otherwise stated. 